\title{
Advances by Selective Breeding for Aquatic Species: A Review
}

\author{
Trygve Gjedrem, Nick Robinson \\ Nofima, Osloveien 1, 1430 Ås, Norway \\ Email: Trygve.Gjedrem@Nofima.no
}

Received 21 August 2014; revised 20 September 2014; accepted 21 October 2014

Copyright (C) 2014 by authors and Scientific Research Publishing Inc.

This work is licensed under the Creative Commons Attribution International License (CC BY). http://creativecommons.org/licenses/by/4.0/

c) (i) Open Access

\begin{abstract}
During the last 40 years it has been shown that well planned family-based breeding programs yield high rates of genetic improvement for aquatic species. The genetic gain has been greater than $\mathbf{1 2 \%}$ per generation for growth rate and for disease resistance when challenge tests are applied. The main reasons for the large genetic gains observed for aquatic species are their relatively high fertility and the natural existence of broad genetic variation for economically important traits, both of which allows a very high selection intensity to be applied. However, the genetic improvement of species grown in aquaculture is far behind that achieved for animals and plants. In 2010 less than $10 \%$ of aquaculture production was based on genetically improved stocks. Breeding programs for aquatic species should be family based and include new biotechnologies like genomic selection.
\end{abstract}

\section{Keywords}

\section{Aquaculture, Selection, Advances, Genetic Gain}

\section{Introduction}

The cradle of aquaculture was in China more than 4 thousand years ago. Today Asia is still dominating aquaculture production. In 2011, 14 countries had a production of more than 0.5 million tons (10 of them in Asia), representing 92\% of world production in fish and shellfish [1]. The 4 non-Asian countries were: Norway (1.1 mill tons) Egypt and Chile (1.0 mill tons) and Brazil (0.6 mill tons). Production takes place under very different environmental conditions. Production in fresh water dominates (62\%), with $8 \%$ in brackish water and $30 \%$ in marine waters [1]. Freshwater earthen ponds are mostly used sometimes combined with recirculating units. The marine production of fish usually takes place in cages while shellfish is often stocked in socks attached to long lines. 
Aquaculture is the fastest growing sector producing meat protein (Table 1). The prognoses are that aquaculture production will pass the catch from wild fisheries in 2018 if the management of wild fishery catches remains limited to about 90 million tons per year. If the expansion of aquaculture production continues it will be at the same level as poultry and pork production in a few years time. Aquaculture also comprises the production of seaweeds which reached 21 million tons in 2011 and is expanding at a rate of $10 \%$ per year [1]. Much of the seaweed produced is consumed by humans.

Selective breeding for plant production started around 1900 as pioneering experiments by Mendel were rediscovered [3]. The same methods were applied to farm animals some 15 years later [4]. The majority of plants and farm animal production is presently based on genetically improved seeds and stocks. Genetic improvement in aquaculture, however, lags far behind plants and farm animals. The first family-based breeding program was started in 1975 [5] and in 2010 it was reported that only 8.2\% of aquaculture production was based on genetically improved stocks [6] [7].

The first reported selection experiments in aquaculture date back to the 1920s. Brook trout was selected for reduced mortality to furunculosis [8] and for common carp the first selection experiment also dated back to 1920 with the development of two productive strains [9]. A large selection response for reduced mortality due to furunculosis in common carp was reported by researchers in Germany [10].

It took many years before estimates of genetic and phenotypic parameters, which are prerequisites for starting efficient breeding programs, were available for aquatic species. The first estimates of heritability in aquatic species were published in 1917 for the number of vertebrae in viviparous, $h^{2}=0.81$ [11], and weight of fingerlings in common carp, $\mathrm{h}^{2}=0.21$ [12] and $\mathrm{h}^{2}=0.10$ [13]. The heritability of weight 280 days post-fertilization in rainbow trout was 0.29 [14] and at 18 months post-fertilization in oysters was 0.33 [15].

A review article [16] documents that during 1970s and early 1980s a number of heritability estimates were published showing high values for body weight at harvest $\left(\mathrm{h}^{2}=0.37\right.$, average of 11 estimates), relatively low heritabilities for mortality ( $h^{2}=0.13$ for 2 estimates), low heritabilities for meat weight and colour $\left(h^{2}=0.09\right.$ for 2 estimates), low heritabilities for dressing percentage $\left(h^{2}=0.01\right.$ for 3 estimates) and high heritabilities for age at maturity ( $\mathrm{h}^{2}=0.71$ for 1 estimate). At that time few estimates of genetic and phenotypic correlations were available.

Some experiments applying mass selection did not obtain a genetic response or genetic gain is measured improvement in a trait due to selection. No selection response was obtained during 6 generations of mass selection for increased growth rate while some response was achieved for reduced growth rate in common carp [17]. In Nile tilapia no response was obtained for mass selection of increased growth rate [18]-[20]. Thus the first selection experiments for fish gave varying results. These reports about common carp and tilapia led to speculation that selection does not work for aquatic species.

\section{Development of Breeding Plans}

Pioneering work in quantitative genetics, which is the theoretical basis for breeding programs, was published in a series of papers during the years 1920-1923 by Sewall Wright (reviewed in [21] [22]). For practical application of the theory, such as the development of breeding plans for farm animals, the books of Lush [23] and then of Falconer [24] were important references.

Selective breeding is the dominant breeding method in farm animals. Individual selection is practiced in all species for traits which can be recorded on breeding candidates, and progeny testing of males is often used. The advantage of progeny testing is that it is possible to get high selection accuracy for economically important traits. The disadvantage is that the generation interval is increased (normally doubled). Limits are normally placed on

Table 1. Production of meat from farm animals and fish, million tons [2].

\begin{tabular}{ccccc}
\hline Species & 2011 & 2012, estimate & 2013, F'cast & \% change per year \\
\hline Beef and veal meat & 67.3 & 67.4 & 67.5 & 0.2 \\
Poultry meat & 102.6 & 104.9 & 106.8 & 2.0 \\
Pig meat & 109.2 & 112.7 & 114.6 & 2.5 \\
Fish capture & 93.5 & 90.6 & 90.1 & -1.8 \\
Aquaculture & 62.7 & 66.3 & 69.9 & 5.7 \\
\hline
\end{tabular}


inbreeding because it leads to depression of fitness and reduced genetic variation. In some breeding programs lines are developed and crossed to obtain a heterosis effect [25].

During the last sixty years the majority of the main farmed species (cattle, pigs, poultry and sheep) have been under systematic breeding programs and farmers have been able to enjoy increased productivity from their herds. The genetic gain obtained varies considerably from $1 \%$ to $5 \%$ per generation ([7] refers to Gjedrem and Baranski, 2009).

\section{Breeding Programs for Aquatic Animals}

Recent reviews have summarized knowledge about the design of breeding programs [26] and breeding plans [27] for aquatic species. There are a number of ways in which the breeding of aquatic species differs from other livestock, and this is often due to the very high fecundity of aquatic species. A big advantage with most aquatic species is that large numbers of female gametes are released into the water where fertilization takes place. This makes it easy to collect egg and sperm (for example, by stripping selected parents) in order to produce large numbers of controlled matings.

The first breeding programs for aquatic species used individual or mass selection, particularly for growth rate, which is of large economic importance and is easy to record on breeding candidates. However, early work to make genetic improvement using mass selection was unsuccessful [17]-[20]. We now believe this is likely to be because of the high accumulated effects of inbreeding resulting in depression of fitness under these schemes. Because of the very high fertility of fish and shellfish, and the high contribution of a few fish to particular mass spawning events, mass spawning can quickly lead to a high rate of inbreeding which depresses the fitness of traits of importance such as growth rate. If the mating of animals sharing common ancestors is not avoided, mass selection can result in poor or even negative effects on traits in the breeding objective. Changes to the mating design or the use of DNA pedigree testing can be used to greatly improve the results of mass selection. For instance, inbreeding can be kept as low as $1 \%$ per generation if a minimum of 50 pairs of breeders are selected per generation and if the number of progeny tested is restricted and standardized to no more than 30-50 per pair of parents [28]. However, mass selection has further limitations. It is only possible to select for traits which can be recorded on the breeders, and in practice that means body weight. So if one wants to select for more traits than body weight other methods of selection should be used.

Inbreeding has been shown to cause a marked depression in most economic traits and a reduction in genetic variation [29] [30]. A review of literature concerning the effects of inbreeding in fish and shellfish [31] listed 28 references which showed inbreeding depression between $0.9 \%$ and $21.7 \%$ per $10 \%$ of inbreeding. It is therefore very important to avoid inbreeding in breeding programs for aquatic species. An increase of $0.1 \%$ inbreeding per generation is generally considered to be acceptable.

A number of crossbreeding experiments have been published. In many instances the crossing of strains and species can lead to hybrids with increased growth rates and survival. High heterosis was obtained by crossing different strains of common carp developed in Israel [32], Hungary [33] [34] and Russia [35]. A crossbreeding experiment with six strains of rohu carp did not show significant heterosis for survival and harvest weight [36]. For Nile tilapia a cross between eight strains showed large variation in heterosis, varying from -5.2 to $14 \%$ [37]. Therefore, the effects of heterosis vary between different strains and the possibility for heterosis needs to be determined on a case-by-case basis.

The high fecundity of aquatic species opens the possibility to apply family selection [23]. This is a better option than progeny testing because the generation interval is shorter leading to higher rates of genetic improvement. Family selection is of particularly interest for traits with low heritability [38]; sib testing makes it possible to get records of meat quality traits and estimates of disease resistance, and to estimate family breeding values on which to base the selection of candidates for breeding. One of the weaknesses with family selection is that the maintenance of family identification can be costly when fry are communally reared up to tagging size. Higher genetic gains have been achieved using communal rearing of families in mixed tanks compared with when families are reared in different tanks [39]. However, family identification can be achieved using DNA testing, and these technologies are becoming more reliable and cheaper every year.

One of the problems hindering the development of breeding programs in aquaculture is the large number of species farmed. In 2005, 241 species were farmed and 124 species had a production of 1000 tons or higher [40]. In order for the benefits from selective breeding to out-weigh the costs of running a family-based breeding pro- 
gram, some have estimated that the industry which the breeding program services generally needs to produce over 40,000 tons (Rye, M. personal com., depending on the farming methods, value of the species per kg farm gate etc.). However, more than 70 species have production volumes in excess of 40,000 tons, and the production of each species frequently takes place in different countries, which can cause cooperation problems. In farm animals they do not face this problem since less than 20 species are farmed and only 6 species (pigs, cattle, poultry, sheep, goats and horses) represent the majority of production.

Since the first family-based breeding program for Atlantic salmon was started in 1975 [5] the international development of selective breeding programs for aquatic species has been slow [6] [7].

\section{Results from Selective Breeding}

Since 1975, the results of a large number of selection experiments and breeding programs for aquatic species have been reported. Gjedrem and Rye [41], have reviewed the average genetic gains for the most important economic traits in these breeding programs which is summarised in Table 2.

The genetic gain in body weight is very high at $12.7 \%$ per generation. With this high genetic gain it is possible to double growth rate in 6 generations as has been achieved in Nile tilapia and Atlantic salmon. Body weight was increased by $85 \%$ and $115 \%$ over 5 generations of selection for increased growth rate in tilapia [42] and Atlantic salmon [43] respectively. In addition, a correlated response in the reduced food conversion rate (FCR) of $23 \%$ was obtained during these 5 generations of selection [43].

Average genetic gains of $12.5 \%$ per generation for increasing disease resistance are very promising. The diseases and species included in the calculation of this average rate are: 1 estimate for IPN resistance in Atlantic salmon, 1 estimate for Vibrio salmonicida in rainbow trout, 2 estimates for white spot disease in Penaeus vannamei, 2 estimates for Taura syndrome in P. vannamei and 1 estimate for Marteilia Sydney parasite in Atlantic salmon. New biotechnology advances open new possibilities to improve disease resistance. A QTL has been found which explains more than $80 \%$ of the genetic variation for IPN resistance in Atlantic salmon [44] [45]. These promising results from selective breeding, along with the application of findings from biotechnology research, have shown that it is possible to develop highly resistant strains of fish and shellfish.

The genetic gain obtained for body weight and disease resistance is four to five times higher compared with gains for these same traits achieved with selective breeding of farm animals [46]. There are two main reasons for this difference between groups of species:

1. The very high fecundity in fish and shellfish allows a much higher selection intensity compared with what is possible for meat producing farm animals.

2. The coefficient of variation in body weight (CV) is more than 2 times higher in aquatic species compared with the CV of body weight in meat producing animals [46].

Genetic gains achieved for filet yield (Nile tilapia) and meat yield (mussel) are very low. This is explained by the high genetic correlation $\left(r_{G}=1\right)$ between body weight and weight of fillet [47].

\section{Conclusion}

Gjedrem, Robinson and Rye [48] have calculated that there is potential for a 20-fold increase in world aquaculture production, the main limiting factor being the availability of feed resources for fin fish. With a potential genetic gain of $12.5 \%$ per generation, aquaculture production could be doubled in 13 years if selective breeding was applied to all farmed animals.

It is particularly interesting that high genetic variation has been detected for resistance to all the major diseases and parasites affecting fish and shellfish in studies to date, and that by applying challenge testing it is

Table 2. Genetic gain obtained in selection experiments and breeding programs [41].

\begin{tabular}{ccc}
\hline Traits & $\begin{array}{c}\text { Average genetic gain per } \\
\text { generation, \% }\end{array}$ & No of estimates \\
\hline Body weight & 12.7 & 61 \\
Filet and meat yield & 0.7 & 3 \\
Survival & 6.4 & 3 \\
Disease resistance & 12.5 & 7 \\
\hline
\end{tabular}


possible to obtain an average genetic gain of $12.5 \%$ per generation, and to generate strains of fish and shellfish with high resistance to serious diseases. Thus in the future it should be possible to reduce the use of antibiotics as well as vaccines in aquaculture.

However, the successful development of selective breeding programs for aquatic species faces a number of challenges. A large number of species are farmed, each having unique biological requirements, reproductive strategies and economics. There is a need to develop innovative ways of overcoming the unique challenges faced when selectively breeding new species. Basic knowledge is lacking about phenotypic and genetic parameters for economically important traits. Such knowledge is required to develop family-based selective breeding programs. In addition to the need for basic technical knowledge is the need for farmers to form organizations to initiate breeding programs. Such organizations, whether be run as not-for-profit cooperatives (such as growers associations) or fully commercial independent businesses, are needed to secure the necessary investments for meeting the running costs of the program. However, $68 \%$ of total world aquatic animal production is derived from 14 species [1], and we therefore recommend that genetic improvement efforts focus on species where the largest impact on food production, and greatest economic benefits, can be realized.

\section{References}

[1] FAO (2011) FAO Yearbook. Fisheries and Aquaculture Statistics, 79.

[2] FAO (2013) Food Outlook. Biannual Report on Global Food Markets, 133.

[3] Mendel, G.J. (1866) Versuche über Plantzenhybriden. Verhandlungen Naturforschung Vereins Brünn, 4, 3-47.

[4] Hagedoorn, A.L. (1950) Animal Breeding. Crosby Lockwood \& Son Ltd., London.

[5] Gjedrem, T. (2010) The First Family-Based Breeding Program in Aquaculture. Review in Aquaculture, 2, 2-15. http://dx.doi.org/10.1111/j.1753-5131.2010.01011.x

[6] Neira, R. (2010) Breeding in Aquaculture Species: Genetic Improvement Program in Developing Countries. 9th World Congress on genetics Applied to Livestock Production, Lipzig, 1-6 August 2010, 8.

[7] Rye, M., Gjerde, B. and Gjedrem, T. (2010) Genetic Development Programs for Aquaculture Species in Developed Countries. 9th World Congress on Genetics Applied to Livestock Production, Lipzig, 1-6 August 2010, 8.

[8] Embody, G.C. and Hyford, C.D. (1925) The Advantage of Rearing Brook Trout Fingerlings from Selected Breeders. Transactions of the American Fisheries Society, 55, 135-138. http://dx.doi.org/10.1577/1548-8659(1925)55[135:TAORBT]2.0.CO;2

[9] Kirpichnikov, V.S. (1987) Selection and New Breeds of Pond Fishes in the USSR. In: Tiewes, K. (Ed.), Selection, Hybridization and Genetic Engineering in Aquaculture, Volume II, 461-473.

[10] Schaperclaus, W. (1962) Trate de Pisciculture en Etang. Vigot Freres, Paris, 208-227.

[11] Schmidt, J. (1917) Racial Investigations. I. Zoarces viviparous L. and Local Races of the Same. Comptes Rendus des Travaux du Laboratoire Carlsberg, 13, 279-396.

[12] Nemashev, G.A. (1969) Heritability of Several Traits Important in the Common Carp Selection. Izvestija Gosudarstvennogo Nauchno-issledovatelskogo, Instituta Ozernogo i Rechnogo Rybnogo Khosjaistva (GosNIORKh), Vol. 65, 185-195.

[13] Kirpichnikov, V.S. (1972) Theory of Fish Selection. In: Cherfas, B.I., Ed., Genetics. Selection and Hybridization of Fish, Academy of Sciences of the USSAR, Israel Program for Scientific Translations, Jerusalem, 299.

[14] Aulstad, D., Gjedrem, T. and Skjervold, H. (1972) Genetic and Environmental Sources of Variation in Length and Weight of Rainbow Trout (Salmo gairdneri). Journal of the Fisheries Research Board of Canada, 29, 237-241. http://dx.doi.org/10.1139/f72-042

[15] Lannan, J.E. (1972) Estimating Heritability and Predicting Response to Selection for the Pacific Oyster, Crassostrea gigas. Proceedings of the National Shellfisheries Association, 62, 62-66.

[16] Gjedrem, T. (1983) Genetic Variation in Quantitative Traits and Selective Breeding in Fish and Shellfish. Aquaculture, 33, 51-72. http://dx.doi.org/10.1016/0044-8486(83)90386-1

[17] Moav, R. and Wohlfarth, G.W. (1976) Two Way Selection for Growth Rate in the Common Carp (Cyprinus carpio L.). Genetics, 82, 83-101.

[18] Hulata, G., Wohlfarth, G.W. and Halevy, A. (1986) Mass Selection for Growth Rate in the Nile Tilapia (Oreochromis niloticus). Aquaculture, 57, 177-184. http://dx.doi.org/10.1016/0044-8486(86)90195-X

[19] Teichert-Coddington, D.R. and Smitherman, O. (1988) Lack of Response by Tilapia Nilotica to Mass Selection for Rapid Early Growth. Transactions of the American Fisheries Society, 117, 297-300. 
http://dx.doi.org/10.1577/1548-8659(1988)117<0297:LORBNT>2.3.CO;2

[20] Huang, C.M. and Liao, I.C. (1990) Response to Mass Selection for Growth Rate in Oreochromis niloticus. Aquaculture, 85, 199-205. http://dx.doi.org/10.1016/0044-8486(90)90019-J

[21] Wright, S. (1940) Breeding Structure of Populations in Relation to Speciation. American Naturalist, 74, $232-248$. http://dx.doi.org/10.1086/280891

[22] Wright, S. (1951) The Genetic Structure of Populations. Annals of Eugenics, 15, 323-354. http://dx.doi.org/10.1111/j.1469-1809.1949.tb02451.x

[23] Lush, J.L. (1945) Animal Breeding Plans. 3rd Edition, Collegiate Press, Ames, 443.

[24] Falconer, D.S. (1960) Quantitative Genetics. Oliver \& Boyd, Edinburgh, London, 365 p.

[25] Bacon, L.D., Hunt, H.D. and Cheng, H.H. (2000) A Review of the Development of Chicken Lines to Resolve Genes Determining Resistance to Diseases. Poultry Science, 79, 1082-1093. http://dx.doi.org/10.1093/ps/79.8.1082

[26] Gjerde, B. (2005) Design of Breeding Programs. In: Gjedrem, T., Ed., Selection and Breeding Programs in Aquaculture, Springer, Berlin, Heidelberg, 364.

[27] Gjedrem, T. (2005) Breeding Plans. In: Gjedrem, T., Ed., Selection and Breeding Programs in Aquaculture, Springer, Berlin, Heidelberg, 364.

[28] Bentsen, H.B. and Olesen, I. (2002) Designing Aquaculture Mass Selection Programs to Avoid High Inbreeding Rates. Aquaculture, 204, 349-359. http://dx.doi.org/10.1016/S0044-8486(01)00846-8

[29] Gjerde, B., Gunnes, K. and Gjedrem, T. (1983) Effect of Inbreeding on Survival and Growth in Rainbow Trout. Aquaculture, 34, 327-332. http://dx.doi.org/10.1016/0044-8486(83)90212-0

[30] Kincaid, H.L. (1983) Inbreeding in Fish Populations Used for Aquaculture. Aquaculture, 33, 215-227. http://dx.doi.org/10.1016/0044-8486(83)90402-7

[31] Fjalestad, K.T. (2005) Breeding Strategies. In: Gjedrem, T., Ed., Selection and Breeding Programs in Aquaculture, Springer, Berlin, Heidelberg, 145-158. http://dx.doi.org/10.1007/1-4020-3342-7_10

[32] Moav, R., Hulata, G. and Wohlfarth, G. (1975) Genetic Differences between the Chinese and European Races of the Common Carp. I. Analysis of Genotype and Environment Interactions for Growth Rate. Heredity, 34, 323-340. http://dx.doi.org/10.1038/hdy.1975.42

[33] Bacos, J. (1979) Crossbreeding Hungarian Races of Common Carp to Develop More Productive Hybrids. In: Pillay, T.V.R. and Dill, W.A., Eds., Advances in Aquaculture, Fishing News Books Ltd., Farnham, 633-635.

[34] Nielsen, H.M., Ødegård, J., Olesen, I., Gjerde, B., Ardo, L., Jeney, G. and Jeney, Z. (2010) Genetic Analysis of Common Carp (Cyprinus carpio) Strains. I: Genetic Parameters and Heterosis for Growth Traits and Survival. Aquaculture, 304, 14-21. http://dx.doi.org/10.1016/j.aquaculture.2010.03.016

[35] Kirpicnikov, V.S., Ilyasov, J.I., Shart, L.A., Vikhman, A.A., Ganchenko, M.V., Ostashevsky, A.L., Simonov, V.M., Tikhonov, G.F. and Tjurin, V.V. (1993) Selection of Kranodar Common Carp (Cyprinus carpio L.) for Resistance to Dropsy: Principal Results and Prospects. Aquaculture, 111, 7-20. http://dx.doi.org/10.1016/0044-8486(93)90020-Y

[36] Gjerde, B., Reddy, P.V.G.K., Mahapatra, K.D., Saha, J.N., Jana, R.K., Meher, P.K., Sahoo, M., Lenka, S., Govindassamy, P. and Rye, M. (2002) Growth and Survival in Two Complete Diallele Crosses with Five Stocks of Rohu carp (Labeo rohita). Aquaculture, 209, 103-115. http://dx.doi.org/10.1016/S0044-8486(01)00848-1

[37] Bentsen, H.B., Eknath, A.E., Pallada-de Vera, M.S., Danting, J.C., Bolivar, H.L., Reyes, R.A., Dionisio, E.E., Longalong, F.M., Circa, A.V., Tayamen, M.M. and Gjerde, B. (1998) Genetic Improvement of Farmed Tilapias: Growth Performance in a Complete Diallel cross Experiment with Eight Strains of Orechromis niloticus. Aquaculture, 160, 145-173. http://dx.doi.org/10.1016/S0044-8486(97)00230-5

[38] Falconer, D.S. and Mackay, T.F.C. (1996) Quantitative Genetics. Longman, Harlow, 464.

[39] Vandeputte, M., Dupont-Nivet, M., Haffray, P., Chavanne, H., Cenadelli, S., Parati, K., Vidal, M.O., Vergent, A. and Chatain, B. (2009) Response to Domestication and Selection for Growth in the European Sea Bass (Dicentrarchus labrax) in Separate and Mixed Tanks. Aquaculture, 286, 20-27. http://dx.doi.org/10.1016/j.aquaculture.2008.09.008

[40] Gjedrem, T. and Rye, M. (2014) Selection Response in Fish and Shellfish: A Review. Manuscript, 16.

[41] Bentsen, H.B., Eknath, A.E., Rye, M., Thodesen, J. and Gjerde, B. (2003) Genetic Improvement of Farmed Tilapias. Response to Selection for Growth Performance in the GIFT Project. International Association for Genetics in Aquaculture VLLL, 9-15 November 2003, Puerto Varas, 68.

[42] Moen, T., Baranski, M., Soneson, A. and Kjøglum, A. (2009) Conformation and Fine-Mapping of a Major QTL for Resistance in Infectious Pancreatic Necrosis in Atlantic Salmon (Salmo salar): Population-Level Associations between Markers and Traits. BMC Genomics, 10, 368. http://dx.doi.org/10.1186/1471-2164-10-368

[43] Thodesen, J., Grisdale-Helland, B., Helland, S.J. and Gjerde, B. (1999) Feed Intake, Growth and Feed Utilization of 
Offspring from Wild and Selected Atlantic Salmon (Salmo salar). Aquaculture, 180, 237-246. http://dx.doi.org/10.1016/S0044-8486(99)00204-5

[44] Housten, R.D., Hamilton, A., Guy, D.R., Tinch, A.E., Taggard, J.B., McAndrew, B.J. and Bishop, S.C. (2008) Major Quantitative Trait Loci Affect Resistance to Infectious Pancreatic Necrosis in Atlantc Salmon (Salmo salar). Genetics, 178, 1109-1115. http://dx.doi.org/10.1534/genetics.107.082974

[45] Gjedrem, T. and Baranski, M. (2009) Selective Breeding in Aquaculture: An Introduction. Springer, 221. http://dx.doi.org/10.1007/978-90-481-2773-3

[46] Gjerde, B., Mengistu, S.B., Ødegård, J., Johansen, H. and Altamirano, D.S. (2012) Quantitative Genetics of Body Weight, Fillet Weight and Fillet Yield in Nile Tilapia (Oreochromis niloticus). Aquaculture, 342-343, 117-124. http://dx.doi.org/10.1016/j.aquaculture.2012.02.015

[47] Gjedrem, T., Robinson, N. and Rye, M. (2012) The Importance of Selective Breeding in Aquaculture to Meet Future Demands for Animal Protein: A Review. Aquaculture, 350-353, 117-129. http://dx.doi.org/10.1016/j.aquaculture.2012.04.008

[48] FAO (2007) FAO Yearbook. Fisheriey Statistics, 2005, 100/2, 206. 
Scientific Research Publishing (SCIRP) is one of the largest Open Access journal publishers. It is currently publishing more than 200 open access, online, peer-reviewed journals covering a wide range of academic disciplines. SCIRP serves the worldwide academic communities and contributes to the progress and application of science with its publication.

Other selected journals from SCIRP are listed as below. Submit your manuscript to us via either submit@scirp.org or Online Submission Portal.
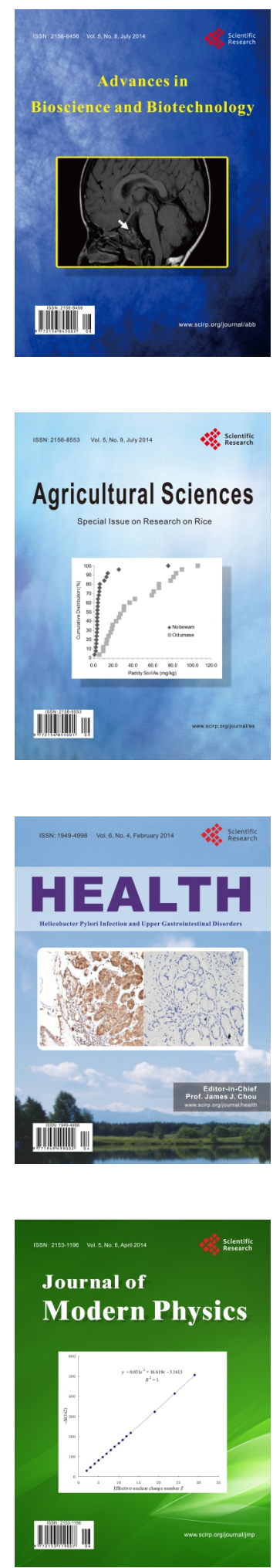
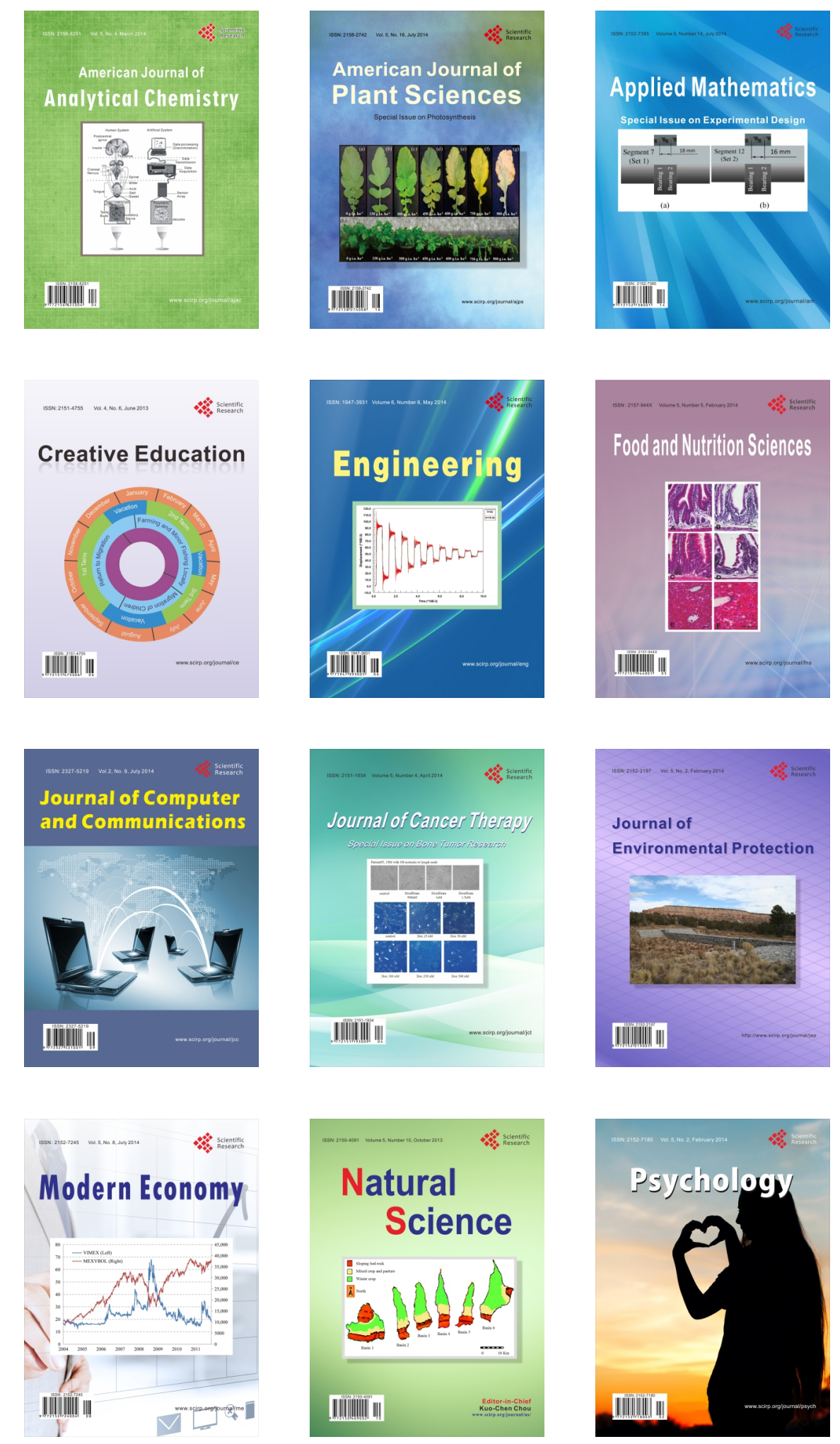